\title{
Anna Doś
}

Uniwersytet Ekonomiczny w Katowicach

e-mail: anna.dos@ue.katowice.pl

\section{ZNACZENIE SPOLECZNEJ ODPOWIEDZIALNOŚCI BIZNESU DLA EFEKTYWNOŚCI \\ FINANSOWEJ PRZEDSIĘBIORSTWA - WSPÓLCZESNE KIERUNKI BADAŃ}

\section{CORPORATE SOCIAL RESPONSIBILITY - CORPORATE FINANCIAL PERFORMANCE LINK: THE CONTEMPORANEOUS TRENDS IN EMPIRICAL STUDY DESIGNS}

DOI: $10.15611 /$ pn.2018.532.06

JEL Classification: M14, L21, L25

\begin{abstract}
Streszczenie: Celem niniejszego artykułu jest rozpoznanie i ocena światowych trendów w zakresie projektowania badań empirycznych ukierunkowanych na dostarczenie ewidencji występowania związku pomiędzy CSR a efektywnością finansową. Metodą zastosowaną w badaniu jest krytyczna analiza literatury światowej. Zważywszy na dynamiczny rozwój badań w wybranym obszarze oraz zamiar wychwycenia najnowszych trendów, w badaniu uwzględniono artykuły opublikowane po 2010 r. Analiza wykazała, że współcześnie znacznie ewoluuje metodyka aproksymacji CSR i efektywności finansowej. Poszukuje się także nowych czynników mogący mieć znaczenie moderujące zależność między CSR a efektywnością finansową. Ze zwiększoną uwagą uwzględnia się też znaczenie kontekstu instytucjonalnego.
\end{abstract}

Słowa kluczowe: rentowność, etyka biznesu, koszt kapitału, metodyka badań.

Summary: The aim of the paper is to identify modern trends in designing studies providing evidence on CSR-CFP links. The method employed is the critical literature review (studies published after 2010). Main findings are that (1) the approximation of CSR and of financial performance has became more detailed, (2) that studies account for factors moderaating CSRCFP link and (3) there is more attention paid to institutional context.

Keywords: profitability, cost of capital, study methodology. 


\section{Wstęp}

Pośród przedsiębiorstw prowadzących działalność w Polsce można zaobserwować rosnące zaangażowanie w działania z zakresu społecznej odpowiedzialności biznesu (CSR - Corporate Social Responsibility). CSR zakłada zorientowanie działań przedsiębiorstwa na cele finansowe i pozafinansowe, odnoszące się do interesów zarówno właścicieli jak i innych interesariuszy. Koncepcja ta zasadza się na uznaniu, że przedsiębiorstwa, poza zobowiązaniami prawno-ekonomicznymi, mają również zobowiązania społeczne. Takie rozumienie zadań przedsiębiorstwa wydaje się pożądane, gdyż z odpowiedzialnością społeczną przedsiębiorstw wiąże się nadzieje na szybszą reorientację gospodarki w kierunku rozwoju zrównoważonego. Jednakże zaangażowanie przedsiębiorstwa w społeczną odpowiedzialność biznesu może generować również konflikty interesu, co stanowi podstawę formułowana ocen krytycznych względem CSR. Jednocześnie w przypadku, gdy zaangażowanie przedsiębiorstwa w CSR przynosi również korzyści finansowe, niebezpieczeństwo konfliktu interesów pomiędzy różnymi interesariuszami przedsiębiorstwa na tle CSR jest znacznie mniejsze. Równocześnie w literaturze przedmiotu przedstawiana jest argumentacja, iż ewolucja zachodząca w otoczeniu biznesu (zmienione regulacje, wzrost oczekiwań interesariuszy, wzrost świadomości społeczeństwa, globalizacja, tzw. pokolenie milenialsów) spowoduje, że wartość przedsiębiorstw, które nie uwzględnią w strategii odpowiedzialności za oddziaływanie na różne grupy interesariuszy, będzie się obniżać w średnim bądź w długim okresie. Spostrzeżenia te stanowią główne podłoże dla rozwoju badań koncentrujących się na określeniu związku pomiędzy CSR a efektywności finansową.

W literaturze światowej przeważają studia, które w sposób empiryczny potwierdzają pozytywny wpływ CSR na efektywność finansową [Moser, Martin 2012; Wang $i$ in. 2016]. Badania przeprowadzone dla Polski nie pozwalają w sposób jednoznaczny potwierdzić, czy przedsiębiorstwa społecznie odpowiedzialne przynoszą wyższe korzyści finansowe niż pozostałe firmy. Istotne jest zatem podejmowanie głębszych studiów na podstawie bardziej precyzyjnych założeń badawczych. Uszczegółowienie założeń badawczych powinno w pierwszej kolejności odnieść się do trendów, jakie w tym obszarze obserwuje się we współczesnej literaturze światowej. Celem niniejszego artykułu jest rozpoznanie i ocena światowych trendów w zakresie projektowania badań empirycznych ukierunkowanych na dostarczenie ewidencji znaczenia społecznej odpowiedzialności przedsiębiorstw dla efektywności finansowej. Metodą zastosowaną w badaniu jest krytyczna analiza literatury światowej. Przy doborze artykułów zastosowano również metodę snowballingu. Zważywszy dynamiczny rozwój badań w wybranym obszarze oraz zamiar wychwycenia najnowszych trendów, w badaniu uwzględniono artykuły opublikowane po 2010 r. Literaturę uwzględnioną $\mathrm{w}$ badaniu pozyskano z bazy danych Scopus oraz bazy danych Google Scholar. Do analizy wybrano te pozycje literaturowe, które w tytule, słowach kluczowych bądź w abstrakcie zawierały wyrażenia social responsibility oraz financial efficiency, financial performance, firm value, value drivers, capital accessibility. 


\section{Efektywność finansowa w kontekście społecznej odpowiedzialności biznesu - podłoże teoretyczne}

Główną przesłanką uznawania efektywności finansowej za cel nadrzędny jest przyjęcie, że cele właścicieli - ze względu na ponoszone przez nich ryzyko rezydualne - powinny być priorytetem względem celów pozostałych grup interesariuszy. Jest to wsparte założeniem, że pozostali interesariusze chronieni są w ramach kontraktów zawartych pomiędzy nimi a przedsiębiorstwem. Satysfakcjonujące wyniki finansowe gwarantują kontynuację zaangażowania kapitału własnego w przedsiębiorstwo - uniknięcie dezinwestycji), co jest zbieżne z interesem menedżerów. Działanie na rzecz maksymalizacji wartości dla właścicieli jest równocześnie legitymizowane zasadą gospodarowania przez menedżerów powierzonym majątkiem z troską i lojalnością (obowiązek fiducjarny). Ostatecznie - zarządzanie zorientowane na kreację wartości dla właścicieli jest zarządzaniem zintegrowanym ze względu na cel i ze względu na narzędzia.

Społeczną odpowiedzialność biznesu definiuje się jako zachowanie przedsiębiorstwa wobec społeczeństwa, polegające na stałym zaangażowaniu biznesu w etyczne postępowanie i przyczyniającym się do ekonomicznego rozwoju z równoczesnym ulepszaniem życia pracowników i ich rodzin, jak również lokalnej społeczności i całego przedsiębiorstwa [Nakonieczna 2008, s. 19]. Określa się ją również jako koncepcję, zgodnie z którą przedsiębiorstwa dobrowolnie uwzględniają problematykę społeczną i ekologiczną w swojej działalności komercyjnej i stosunkach z interesariuszami [Adamczyk 2009, s. 42]. CSR wyraża się w działaniu zorientowanym na szerokie spektrum celów [Lewicka-Strzałecka 2006] obejmujące cele finansowe i pozafinansowe, cele właścicieli i cele pozostałych grup interesariuszy. Takie rozumienie zadań przedsiębiorstwa wydaje się pożądane, gdyż z odpowiedzialnością społeczną przedsiębiorstw wiąże się nadzieje na szybszą reorientację gospodarki w kierunku rozwoju zrównoważonego. Koncepcja ta stwarza bowiem obszar większego zaangażowania świata biznesu w redukowanie negatywnych efektów zewnętrznych, w dostarczanie dóbr publicznych, jak również w przyjęcie perspektywy długoterminowej w programowaniu działań gospodarczych. Jednakże to, co postrzega się za pożądany kierunek w zarządzaniu przedsiębiorstwami, jest jednocześnie podstawą formułowania ocen krytycznych. Zauważa się, że społeczna odpowiedzialność biznesu generuje konflikty interesów [Barnea, Rubin 2010], koszty agencji [Moser, Martin 2012], jak również może być wykorzystywana jako usprawiedliwienie dla wywierania wpływu na życie społeczno-gospodarcze (działalność polityczna przedsiębiorstw, gdzie menedżer w procesie niedemokratycznym zyskuje władzę, której skala zdeterminowana jest wielkością środków, jakimi zarządza) [Hussain, Moriarty 2016]. Z punktu widzenia ugruntowanych teorii z zakresu zarządzania finansami przedsiębiorstwa wątpliwości nie budzą takie działania z zakresu CSR, które oprócz korzyści społecznych i środowiskowych przynoszą przedsiębiorstwu korzyści finansowe, a tym samym przyczyniają się do wzrostu wartości dla właścicieli. Jednocześnie też podkreśla się, że zaangażowanie w społeczną odpowie- 
dzialność - w sytuacji ewoluującego otoczenia przedsiębiorstw - jest warunkiem koniecznym kreacji wartości w średnim i długim okresie [Falck, Heblich 2007]. Szczególnym tego wyrazem jest wprowadzona ostatnio zmiana nomenklatury w raportowaniu działań z zakresu CSR. Działania te i ich efekty, które dotychczas nazywane były czynnikami nie-finansowymi, w myśl obecnych rekomendacji określa się jako ,prefinansowe” [ACCA 2017]. Ma to na celu budowanie świadomości, że oddziaływanie na wszelkie grupy interesariuszy nie jest odseparowane od aspektów finansowych i ostatecznie będzie miało znaczenie dla realizacji głównego celu przedsiębiorstwa, jakim jest maksymalizacja wartości dla właścicieli. Rozważania te stymulują zauważalny od lat 90 . XX w. dynamiczny rozwój studiów empirycznych ukierunkowanych na dostarczenie ewidencji relacji, jakie występują pomiędzy CSR a efektywnością finansową. Współczesne kierunki tej ewolucji zostaną przedstawione w dalszej części opracowania

\section{Ewolucja projektowania badań nad relacją pomiędzy społeczną odpowiedzialnością biznesu a efektywnością finansową}

W świetle przywołanych podejść względem wyjaśnienia zasadności CSR i prób projekcji jego konsekwencji szczególnie istotne jest pewniejsze i głębsze rozumienie tego, w jaki sposób i w jakich okolicznościach zaangażowanie w CSR oddziałuje na efektywność finansową przedsiębiorstwa. Pierwsze studia w tym obszarze pojawiały się już w latach 80. XX w., jednak ich dynamiczny rozwój obserwuje się od 2005 r., co ilustruje rys. 1.

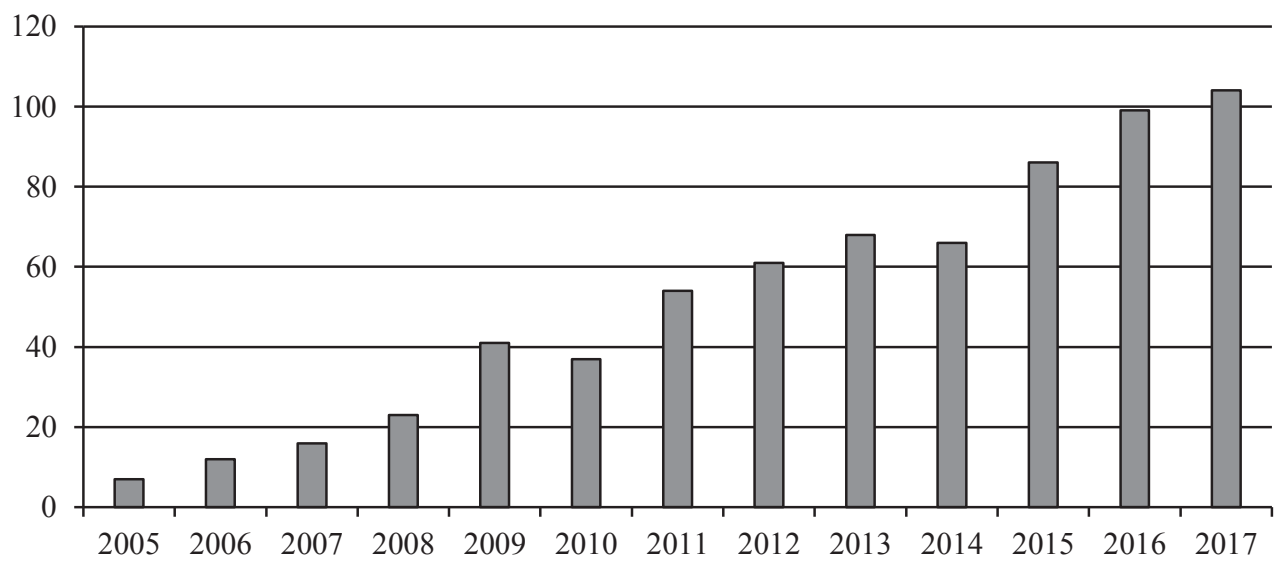

Rys. 1. Liczba publikacji, które w tytule, słowach kluczowych i/lub w streszczeniu zawierają sformułowania dotyczące „społecznej odpowiedzialności” oraz „efektywności finansowej” według bazy danych Scopus w latach 2005-2017

Źródło: opracowanie własne na podstawie danych pozyskanych z bazy danych Scopus. 
Pierwsze studia poszukujące relacji pomiędzy CSR a efektywnością finansową przyjmowały stosunkowo proste założenia badawcze. Dane o społecznej odpowiedzialności biznesu włączano do modelu jako zmienne binarne (spółka jest notowana/ nie notowana na „zrównoważonym” indeksie giełdowym, spółka publikuje/nie publikuje raport/dane na temat CSR), nieco później - wraz z rozwojem infrastruktury rynku inwestowania społecznie odpowiedzialnego, adaptowano zmienne ciągłe (ratingi CSR dostarczane przez m.in. MSCI, Bloomberg, KLD). W pierwszej fazie rozwoju literatury wypracowano też dwa podejścia względem aproksymacji efektywności finansowej: oparte na spojrzeniu rynkowym, gdzie za zmienną przyjmowano wskaźniki odzwierciedlające waloryzację spółki na rynku kapitałowym [Becchetti, Ciciretti 2009; Luo, Bhattacharya 2006] lub oparte na spojrzeniu rachunkowym, gdzie efektywność finansową mierzy się miarami księgowymi [Tsoutsoura 2004; Lu i in. 2014]. Prosty schemat badawczy przeważający w literaturze do $2010 \mathrm{r}$. prezentuje rys. 2 .

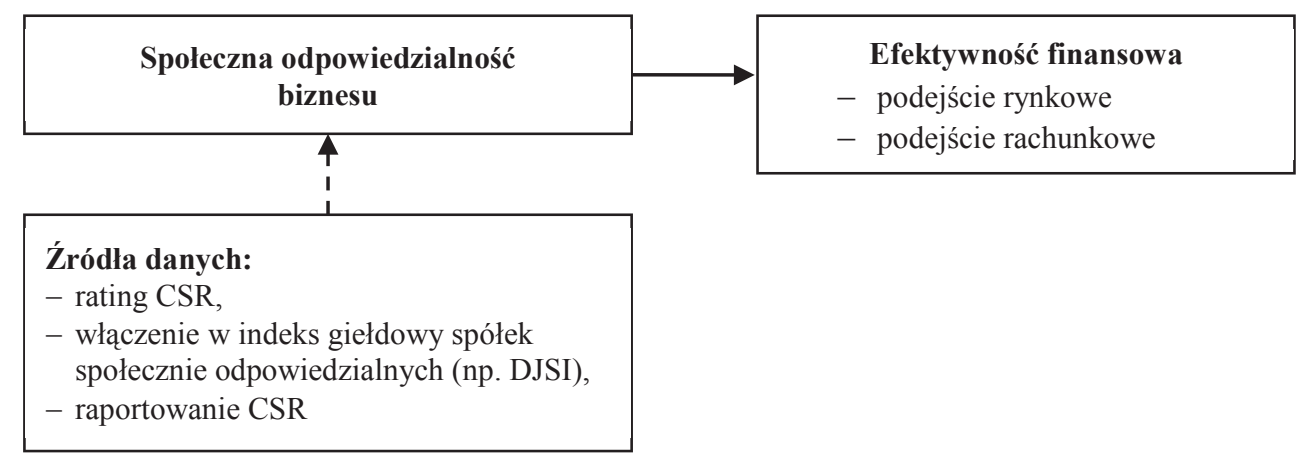

Rys. 2. Projektowanie badań nad znaczeniem społecznej odpowiedzialności biznesu dla efektywności finansowej - ujęcie tradycyjne

Źródło: opracowanie własne.

Dorobek literatury do 2010 r. wskazuje na raczej niejasny związek pomiędzy CSR a efektywnością finansową. Jako przyczynę podawano: brak możliwości określenia i ujednolicenia w ramach próby: (a) zamierzonego horyzontu czasowego działania przedsiębiorstw, (b) efektywności rynku finansowego w zakresie recepcji informacji o rezultatach CSR, (c) rodzaju działań z zakresu CSR, (d) możliwego zróżnicowania w poziomie osiąganych przez przedsiębiorstwo efektów w związku z zaangażowanie w CSR zależnego od reakcji złożonego otoczenia przedsiębiorstwa na fakt dostarczenia dobra [Bénabou, Tirole 2010]. Jednocześnie jednak nagłaśniano wiele tzw. business cases dla CSR, czyli przykładów przedsiębiorstw, które osiągnęły ponadprzeciętne rezultaty finansowe w konsekwencji zaangażowania w CSR (np. przypadek Marks \& Spencer). W konsekwencji podjęto prace nad uszczegółowieniem założeń badawczych tak, aby poszukiwanie związków pomiędzy zmiennymi odzwierciedlało kompleksowy charakter relacji pomiędzy zjawiskami. 
Dotychczasowe badania empiryczne zależności pomiędzy efektywnością finansową a zaangażowaniem w społeczną odpowiedzialność przedsiębiorstwa działających w Polsce odzwierciedlają ,tradycyjny” schemat badawczy (rys. 2). Ich rezultaty wskazują, że przedsiębiorstwa społecznie odpowiedzialne osiągają efekty finansowe zbliżone do pozostałych [Otola, Tylec 2016; Sobczyk 2016], nieznacznie lepsze niż pozostałe [Bek-Gaik, Rymkiewicz 2015; Skrzypek, Saadi 2016] bądź lepsze niż przedsiębiorstwa zdecydowanie społecznie nieodpowiedzialne [Doś 2017]. Takie rezultaty badań nad korzyściami finansowymi płynącymi z CSR mogą oddziaływać w sposób demotywujący - zniechęcając przedsiębiorstwa do angażowania zasobów w społeczną odpowiedzialność biznesu. Brak wiedzy o korzyściach płynących z CSR jest bowiem jedną z najczęściej wskazywanych przez przedsiębiorstwa barier implementacji społecznej odpowiedzialności biznesu [Zuzek 2012]. W tym kontekście szczególnie istotne jest rozeznanie kierunków badań światowych nad związkiem pomiędzy CSR a efektywnością finansową w celu uszczegółowienia założeń badawczych dla specyficznego otoczenia instytucjonalnego, jakim jest rynek polski.

Analiza literatury w zakresie powiązań pomiędzy CSR a efektywnością finansową po 2010 r. pozwala rozpoznać występowanie trzech mocno zaznaczających się trendów (rys. 3).

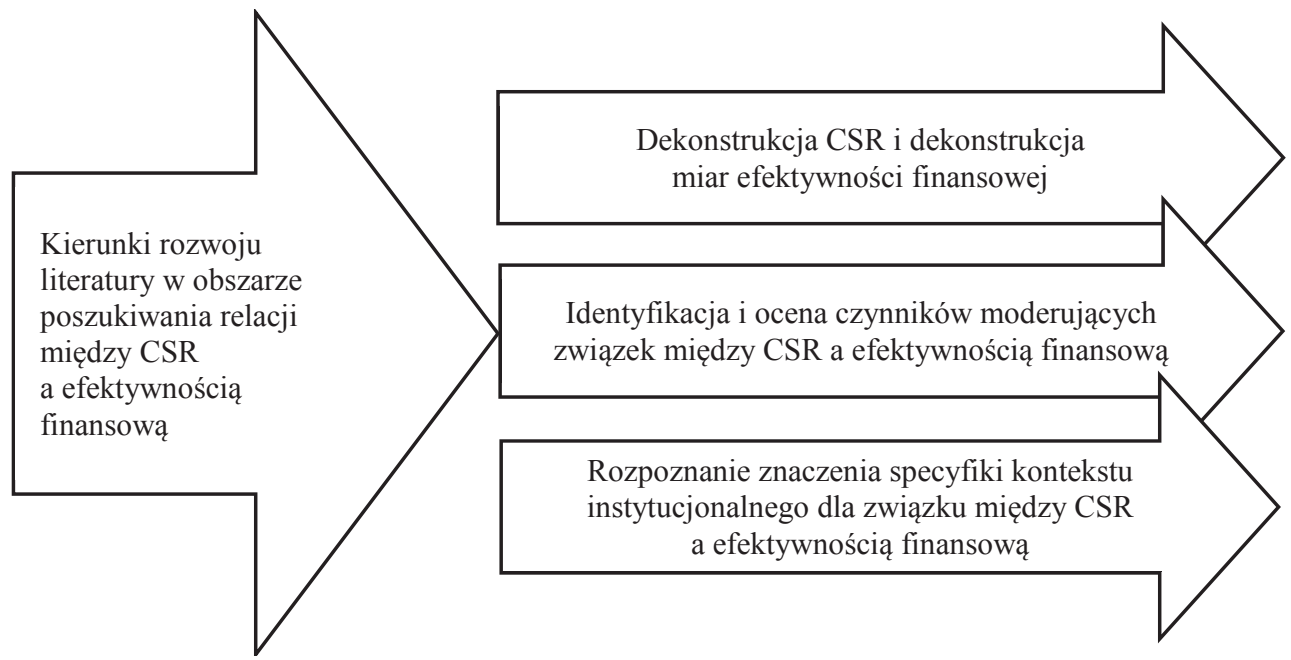

Rys. 3. Kierunki rozwoju literatury w zakresie powiązań pomiędzy CSR a efektywnością finansową po $2010 \mathrm{r}$.

Źródło: opracowanie własne.

Krytyczna analiza literatury przedmiotu po 2010 r. pozwala zauważyć, że rozwój tej literatury w pierwszej kolejności następuje w kierunku identyfikacji powiązań pomiędzy poszczególnymi komponentami konstruktu, jakim jest CSR, i konstruktu, 
jakim jest efektywność finansowa [Lu i in. 2014]. Zważywszy, że społeczna odpowiedzialność biznesu może być rozumiana i wyrażać się w różny sposób, w badaniach empirycznych coraz liczniejsze są studia zakładające dekompozycję CSR na bardziej szczegółowe czynniki będące sposobami realizacji/manifestacji społecznej odpowiedzialności biznesu. Są nimi najczęściej: transparentność w kwestii CSR, reputacja w zakresie CSR określona na podstawie różnych ratingów, audyty społeczne, proces CSR, rezultaty CSR, rodzaj strategii CSR (filantropia, ekoefektywność, komponenty CSR (odpowiedzialność za społeczeństwo, środowisko naturalne czy etyczne praktyki biznesowe) $\mathrm{i}$ inne [Tang i in. 2012; Qiu i in. 2016; Torugsa $\mathrm{i}$ in. 2012; Cavaco, Crifo 2014]. Jednocześnie ewoluuje dobór źródeł danych do analizy. Ratingi CSR wciąż pozostają często wykorzystywanym źródłem, zwłaszcza gdy poza ogólną oceną jakości CSR dostarczają ocen subkategorii CSR (efektywności środowiskowej, społecznej, ładu korporacyjnego). Poza wykorzystywaniem ratingów w badaniach w większym zakresie wykorzystuje się dane pierwotne: ankiety, wywiady. Metodą zyskującą popularność jest analiza treści ujawnianych przez przedsiębiorstwa informacji dotyczących ich zaangażowania w CSR. Ewolucja aproksymacji CSR z jednej strony wynika z potrzeby uwzględnienia heterogeniczności działań z zakresu CSR, a z drugiej jest stymulowana rosnącą transparentnością i standaryzacją raportowania CSR.

Również efektywność finansowa rozważana jest coraz bardziej szczegółowo. Doprecyzowywanie relacji pomiędzy CSR a efektywnością finansową opiera się współcześnie na poszukiwaniu wpływu CSR na czynniki kreacji wartości przedsiębiorstwa. Dekomponuje się zatem również miary efektywności finansowej - zwłaszcza miary księgowe, w poszukiwaniu czynników, które są po pierwsze powszechne dla różnego rodzaju przedsiębiorstw (niespecyficzne) a po drugie mogą być uzależnione także od społecznej odpowiedzialności biznesu. Wśród takich czynników najczęściej uwzględnia się:

- pozycję rynkową (sprzedaż), satysfakcję klientów [Malik 2015; Galbreath, Shum 2012; Lev i in. 2010],

- produktywność, satysfakcję i motywację pracowników [Edmans 2012; Ali i in. 2010],

- obniżenie kosztów [Harjoto, Jo 2011],

- zarządzanie ryzykiem [Oikonomou i in. 2012; Jo, Na 2012],

- koszt kapitału i dostęp do kapitału.

Jednym z rozwijających się dynamicznie nurtów badawczych jest właśnie nurt podejmujący problematykę znaczenia społecznej odpowiedzialności biznesu dla kosztu i dostępu kapitału, które w sposób istotny determinują wartość przedsiębiorstwa. Wiele badań empirycznych potwierdza, że przedsiębiorstwa społecznie odpowiedzialne cechują niższe ryzyko działalności [Godfrey i in. 2009] oraz wyższa transparentność redukująca ryzyko inwestycji w przedsiębiorstwo [Dhaliwal i in. 2011]. Oba te czynniki mają znaczenie z punktu widzenia decyzji o alokacji kapitału podejmowanych przez kapitałodawców. Nurt ten zbiega się z intensyfikacją badań dotyczących inwestowania społecznie odpowiedzialnego. 
Drugim głównym kierunkiem rozwoju literatury w zakresie związków pomiędzy CSR a efektywnością finansową jest poszukiwanie i ocena czynników moderujących zależność pomiędzy CSR a efektywnością finansową. Podkreśla się bowiem, że działania z zakresu społecznej odpowiedzialności biznesu nie oddziałują bezpośrednio ani na wartość przedsiębiorstwa, ani na jej czynniki i istotne jest rozpoznanie stymulatorów i inhibitorów wpływu CSR na efektywność finansową [Saeidi i in. 2015; Mulki, Jaramillo 2011; Aguinis, Glavas 2012]. Jako czynniki moderujące pozytywny wpływ CSR na efektywność finansową bada się m.in.:

- zarządzanie interesariuszami [Ioannou, Serafeim 2015; Dal Maso i in. 2018],

- ład korporacyjny, kulturę korporacyjną [Eccles i in. 2012],

- strategię CSR [Tang i in. 2012],

- luz organizacyjny, satysfakcji właścicieli z dotychczasowych osiągnięć kadry zarządczej [Arora, Dharwadkar 2011],

- skalę komunikacji CSR [Purnomo, Widianingsih 2012],

- przewagę konkurencyjną [Saeidi i in. 2015],

- reputację [Galbreath, Shum 2012].

Zwraca uwagę fakt, że znaczną część dotychczas zidentyfikowanych czynników moderujące związek pomiędzy CSR a efektywnością finansową można uznać za czynniki mające charakter zasobów niematerialnych. Rozwój wiedzy w tym zakresie może zatem inspirować rozwój rachunkowości. Na obecnym etapie rozwoju literatury katalog czynników moderujących związek pomiędzy CSR a efektywnością finansową pozostaje zdecydowanie otwarty.

Trzecim głównym kierunkiem rozwoju badań jest próba określenia znaczenia kontekstu instytucjonalnego dla relacji pomiędzy CSR i efektywnością finansową. Wynika to z założenia, że cele, postępowanie i znaczenie poszczególnych grup interesariuszy różnią się w zależności od kraju czy też rynku [Matten, Moon 2008] Może to mieć znaczenie dla skali i sposobu „wynagradzania” wysiłków przedsiębiorstwa ukierunkowanych na wzięcie odpowiedzialności za oddziaływanie na otoczenie jak również dla skali i sposobu „karania” przedsiębiorstwa za Kontekst instytucjonalny definiuje się w różnorodnych przekrojach. Można zauważyć, że w badanej literaturze uwaga koncentruje się zwłaszcza na:

- kontekście instytucjonalnym rynkowym (typ gospodarki, ceny, kondycja ekonomiczna gospodarki, faza cyklu koniunkturalnego) [Lee i in. 2013; Lee i in. 2013; Ducassy 2013],

- kontekście instytucjonalnym kulturowym (typ kultury, rodzaj religii) [Sun i in. 2018; Javaid, Al-Malkawi 2018].

- kontekście gospodarek narodowych (ze specyficznymi instytucjami formalnymi i nieformalnymi - normami społecznymi i wartościami).

Zauważa się, że w gospodarkach rozwiniętych pozytywny związek pomiędzy CSR a efektywnością finansową jest silniejszy [Wang i in. 2016]. Jako wyjaśnienie podaje się fakt, że w gospodarkach rozwiniętych rynek jest bardziej efektywny a instytucje ustabilizowane. Jest także silniejszy w gospodarkach anglosaskich niż 
w innych rozwiniętych. Tłumaczy się to tym, że dobrowolne zaangażowanie przedsiębiorstw w działania na rzecz środowiska i społeczności lokalnej w gospodarkach liberalnych stanowią substytut zinstytucjonalizowanych form partycypacji interesariuszy [Jackson, Apostolakou 2010]. Jednocześnie coraz liczniejsze są studia dostarczające ewidencji z krajów rozwijających się. Dotyczy to zwłaszcza Azji Południowej, Afryki, krajów arabskich i w mniejszym stopniu - krajów Europy Środkowo-Wschodniej.

Analiza literatury światowej wykazuje, że nastąpiło odejście od uproszczonego postrzegania związku między CSR a efektywnością finansową. Odejście to wyraża się w uszczegółowieniu projektowania badań empirycznych w taki sposób, aby założenia badawcze uwzględniały kompleksowy charakter związków. Współczesne podejście do projektowania studiów z zakresu związku pomiędzy CSR a efektywnością finansową prezentuje rys. 4.

Wyniki analizy trendów występujących w literaturze stanową istotny przyczynek do projektowania studiów w obszarze związków między CSR a efektywnością

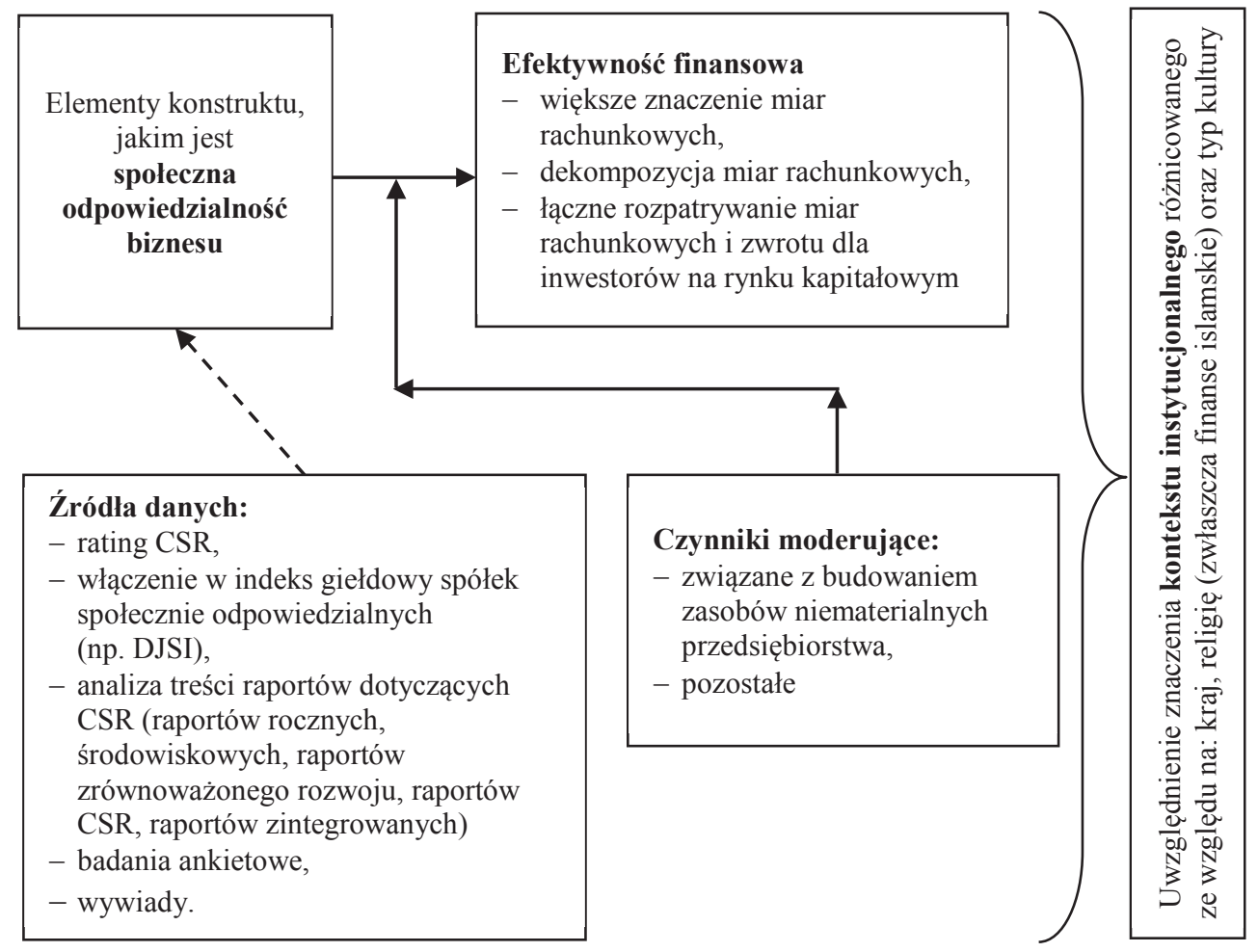

Rys. 4. Projektowanie badań nad znaczeniem społecznej odpowiedzialności biznesu dla efektywności finansowej - ujęcie współczesne

Źródło: opracowanie własne. 
finansową przedsiębiorstw działających w Polsce. Po pierwsze, brak jest uzasadnienia do kontynuowania badań zakładających uproszczony schemat powiązań. Po drugie, wyraźne jest zapotrzebowanie na badania dostarczające ewidencji z uwzględnieniem szczególnych uwarunkowań instytucjonalnych. Polska - stanowiąca przykład gospodarki, która z sukcesem dokonała transformacji w kierunku gospodarki mieszanej, jest w momencie awansu do grupy krajów rozwiniętych i jednocześnie charakteryzuje się szczególnym tłem historycznym i specyfiką kulturową, jest wartościowym polem badawczym.

Celem analizowanych studiów jest rozeznanie, czy wzięcie przez przedsiębiorstwa odpowiedzialności za oddziaływanie na otoczenie, może przyczynić się równocześnie do budowania wartości przedsiębiorstwa. Badania te są zatem poszukiwaniem odpowiedzi na pytanie, czy CSR to droga w kierunku osiągania korzyści w rozumieniu Pareta. Choć rezultaty bywają sprzeczne, przeważają badania potwierdzające pozytywny wpływ CSR na wartość przedsiębiorstw [Moser, Martin 2012; Wang $i$ in. 2016]. Istotne jest zweryfikowanie, czy, jak i w jakich warunkach CSR może przyczynić się do poprawy dobrobytu w Polsce.

\section{Zakończenie}

Szereg przesłanek stymuluje intensywne poszukiwanie związków zachodzących pomiędzy CSR a efektywnością finansową. Istotne jest przy tym ostrożne i wnikliwe projektowanie założeń badawczych tak, aby uniknąć uproszczonego podejścia względem zjawisk, których powiązania mają charakter kompleksowy. Analiza literatury światowej wykazała, że współcześnie znacznie ewoluuje metodyka aproksymacji CSR. Aproksymacja efektywności finansowej rozwija się w kierunku nadania większego znaczenia miarom rachunkowym tej efektywności i ich komponentom. Poszukuje się nowych czynników mogący mieć znaczenie moderujące zależność między CSR a efektywnością finansową (większość tych czynników można uznać za takie, które mają charakter zasobów niematerialnych). Ze zwiększoną uwagą uwzględnia się też znaczenie kontekstu instytucjonalnego. Wyniki artykułu stanowią wkład w projektowanie badań dotyczących korzyści finansowych wynikających z odpowiedzialności biznesu.

\section{Literatura}

ACCA, 2017, Insights into integrated reporting. Challenges and best practice responses, http://integratedreporting.org/wp-content/uploads/2017/04/ACCAInsights_into_Integrated_Reporting.pdf (10.05.2018).

Adamczyk J., 2009, Społeczna odpowiedzialność przedsiębiorstw. Teoria i praktyka, PWE, Warszawa. Aguinis H., Glavas A., 2012, What we know and don't know about corporate social responsibility: A review and research agenda, Journal of Management, vol. 38, no. 4, s. 932-968. 
Ali I., Rehman K., Ali U., Yousaf J., Zia, M., 2010, Corporate social responsibility influences employee commitment and organizational performance, African Journal of Business Management, vol. 4, no. 13 , s. 27-96.

Arora P., Dharwadkar R., 2011, Corporate governance and corporate social responsibility CSR: The moderating roles of attainment discrepancy and organization slack, Corporate Governance: An International Review, vol. 192, s. 136-152.

Barnea A., Rubin A., 2010, Corporate social responsibility as a conflict between shareholders, Journal of Business Ethics, vol. 97, no. 1, s. 71-86.

Becchetti L., Ciciretti R., 2009, Corporate social responsibility and stock market performance, Applied Financial Economics, vol. 19, no. 16, s. 1283-1293.

Bek-Gaik B., Rymkiewicz B., 2015, Wpływ CSR na finansowe miary dokonań jednostek, Zeszyty Naukowe Uniwersytetu Szczecińskiego, nr 854, s. 151-165.

Bénabou R., Tirole J., 2010, Individual and corporate social responsibility, Economica, vol. 77, no. 305, s. 1-19.

Cavaco S., Crifo P., 2014, CSR and financial performance: Complementarity between environmental, social and business behaviours, Applied Economics, vol. 46, no. 27, s. 3323-3338.

Dal Maso L., Mazzi F., Soscia M., Terzani S., 2018, The moderating role of stakeholder management and societal characteristics in the relationship between corporate environmental and financial performance, Journal of Environmental Management, vol. 218, s. 322-332.

Dhaliwal D., Li O., Tsang A., Yang Y., 2011, Voluntary nonfinancial disclosure and the cost of equity capital: The initiation of corporate social responsibility reporting, The Accounting Review, vol. 86 , no. 1 , s. 59-100.

Doś A., 2017, Financial performance and bankruptcy risk of socially responsible and „irresponsible” companies - the Polish case, Financial Management of Firms and Financial Institutions, vol. 201, s. 201-208.

Ducassy I., 2013, Does corporate social responsibility pay off in times of crisis? An alternate perspective on the relationship between financial and corporate social performance, Corporate Social Responsibility and Environmental Management, vol. 20, no. 3, s. 157-167.

Eccles R.G., Ioannou I., Serafeim G., 2012, The impact of a corporate culture of sustainability on corporate behavior and performance, Harvard Business School Working Paper, vol. 201, s. 1-56.

Edmans A., 2012, The link between job satisfaction and firm value, with implications for corporate social responsibility, The Academy of Management Perspectives, vol. 26, no. 4, s. 1-19.

Falck O., Heblich S., 2007, Corporate social responsibility: Doing well by doing good, Business Horizons,vol. 50, no. 3, s. 247-254.

Galbreath J., Shum P., 2012, Do customer satisfaction and reputation mediate the CSR-FP link? Evidence from Australia, Australian Journal of Management, vol. 37, no. 2, s. 211-229.

Godfrey P., Merrill C. Hansen J., 2009, The relationship between corporate social responsibility and shareholder value: An empirical test of the risk management hypothesis, Strategic Management Journal, vol. 30 , no. 4, s. 425-445.

Harjoto M., Jo H., 2011, Corporate governance and CSR nexus, Journal of Business Ethics, vol. 100, no. 1 , s. $45-67$.

Hussain W., Moriarty J., 2016, Accountable to whom? Rethinking the role of corporations in political CSR, Journal of Business Ethics, vol. 149, no. 3, s. 519-534.

Ioannou I., Serafeim G., 2015, The impact of corporate social responsibility on investment recommendations: Analysts' perceptions and shifting institutional logics, Strategic Management Journal, vol. 36, no. 7, s. 1053-1081.

Jackson G., Apostolakou A., 2010, Corporate social responsibility in Western Europe: An institutional mirror or substitute?, Journal of Business Ethics, vol. 94, no. 3, s. 371-394.

Javaid S., Al-Malkawi H., 2018, Corporate social responsibility and financial performance in Saudi Arabia: Evidence from Zakat contribution, Managerial Finance, https://doi.org/10.1108/MF-122016-0366. 
Jo H., Na H., 2012, Does CSR reduce firm risk? Evidence from controversial industry sectors, Journal of Business Ethics, vol. 110, no. 4, s. 441-456.

Lai C., Chiu C., Yang C., Pai D., 2010, The effects of corporate social responsibility on brand performance: The mediating effect of industrial brand equity and corporate reputation, Journal of Business Ethics, vol. 95, no. 3, s. 457-469.

Lev B., Petrovits C., Radhakrishnan S., 2010, Is doing good good for you? How corporate charitable contributions enhance revenue growth, Strategic Management Journal, vol. 31, no. 2, s. 182-200.

Lee S., Seo K., Sharma A., 2013, Corporate social responsibility and firm performance in the airline industry: The moderating role of oil prices, Tourism Management, vol. 38, s. 20-30.

Lee S., Singal M., Kang K., 2013, The corporate social responsibility-financial performance link in the US restaurant industry: Do economic conditions matter?, International Journal of Hospitality Management, vol. 32, s. 2-10.

Lewicka-Strzałecka A., 2006, Odpowiedzialność moralna w życiu gospodarczym, IFiS PAN, Warszawa.

Lu W., Chau K., Wang H., Pan W., 2014, A decade's debate on the nexus between corporate social and corporate financial performance: A critical review of empirical studies 2002-2011, Journal of Cleaner Production, vol. 79, s. 195-206.

Luo X., Bhattacharya C., 2006, Corporate social responsibility, customer satisfaction, and market value, Journal of Marketing, vol. 70, no. 4, s. 1-18.

Malik M., 2015, Value-enhancing capabilities of CSR: A brief review of contemporary literature, Journal of Business Ethics, vol. 127, no. 2, s. 419-438.

Matten D., Moon J., 2008, "Implicit" and "explicit" CSR: A conceptual framework for a comparative understanding of corporate social responsibility, Academy of Management Review, vol. 33, no. 2, s. 404-424.

Moser D., Martin P., 2012, A broader perspective on corporate social responsibility research in accounting, The Accounting Review, vol. 87, no. 3, s. 797-806.

Mulki J., Jaramillo F., 2011, Ethical reputation and value received: customer perceptions, International Journal of Bank Marketing, vol. 29, no. 5, s. 358-372.

Nakonieczna J., 2008, Społeczna odpowiedzialność przedsiębiorstw międzynarodowych, Difin, Warszawa.

Oikonomou I., Brooks C., Pavelin S., 2012, The impact of corporate social performance on financial risk and utility: A longitudinal analysis, Financial Management, vol. 41, no. 2, s. 483-515.

Otola, I. Tylec A., 2016, Społeczna odpowiedzialność biznesu a wyniki finansowe przedsiębiorstw, Zeszyty Naukowe Politechniki Częstochowskiej. Zarządzanie, vol. 24, s. 81-89.

Purnomo P., Widianingsih L., 2012, The influence of environmental performance on financial performance with corporate social responsibility CSR disclosure as a moderating variable: Evidence from listed companies in Indonesia, Review of Integrative Business and Economics Research, vol. 1, no. 1, s. 57-68.

Qiu Y., Shaukat A., Tharyan R., 2016, Environmental and social disclosures: Link with corporate financial performance, The British Accounting Review, vol. 48, no. 1, s. 102-116.

Saeidi S., Sofian S., Saeidi P., Saeidi S., Saaeidi S., 2015, How does corporate social responsibility contribute to firm financial performance? The mediating role of competitive advantage, reputation, and customer satisfaction, Journal of Business Research, vol. 68, no. 2, s. 341-350.

Skrzypek A., Saadi N., 2016, Profitability of socially responsible public listed companies in Poland, Prace Naukowe Uniwersytetu Ekonomicznego we Wrocławiu, nr 423, s. 107-121.

Sobczyk M., 2016, W poszukiwaniu wptywu dokonań CSR na wyniki finansowe, Prace Naukowe Uniwersytetu Ekonomicznego we Wrocławiu, nr 436, s. 261-269.

Sun J., Yoo S., Park J., Hayati B., 2018, Indulgence versus restraint: The moderating role of cultural differences on the relationship between corporate social performance and corporate financial performance, Journal of Global Marketing, vol. 24, s. 1-10. 
Tang Z., Hull C., Rothenberg S., 2012, How corporate social responsibility engagement strategy moderates the CSR-financial performance relationship, Journal of Management Studies, vol. 49, no. 7, s. 1274-1303.

Torugsa N., O'Donohue W., Hecker R,. 2012, Capabilities, proactive CSR and financial performance in SMEs: Empirical evidence from an Australian manufacturing industry sector, Journal of Business Ethics, vol. 109, no. 4, s. 483-500.

Tsoutsoura M., 2004, Corporate social responsibility and financial performance, Center for Responsible Business, vol. 1, s. 1-21.

Wang Q., Dou J., Jia S., 2016, A meta-analytic review of corporate social responsibility and corporate financial performance: The moderating effect of contextual factors, Business \& Society, vol. 55, no. 8, s. 1083-1121.

Zuzek D., 2012, Społeczna odpowiedzialność biznesu a zrównoważony rozwój przedsiębiorstw, Zeszyty Naukowe Małopolskiej Wyższej Szkoły Ekonomicznej w Tarnowie, vol. 2, nr 21, s. 197-207. 